\title{
Dietary effects of chitosan and buckwheat (Fagopyrum esculentum) on the performance and serum lipid profile of broiler chicks
}

\author{
M.A. Sayed ${ }^{1,3 \#, ~ M . T . ~ I s l a m ², ~ M . M . ~ H a q u e ~}{ }^{3}$, M.J.H. Shah ${ }^{3}$, R. Ahmed ${ }^{3}$, \\ M.N. Siddiqui ${ }^{4}$ \& M.A. Hossain ${ }^{5}$ \\ ${ }^{1}$ The United Graduate School of Agricultural Sciences, Iwate University, 3-18-8 Ueda, Morioka, Iwate 020-8550 \\ Japan, ${ }^{2}$ Department of Biotechnology, Bangabandhu Sheikh Mujibur Rahman Agricultural University, Gazipur -1706, \\ Bangladesh, ${ }^{3}$ Department of Biochemistry and Molecular Biology, Hajee Mohammad Danesh Science and Technology \\ University, Dinajpur-5200, Bangladesh, ${ }^{4}$ Department of Biochemistry and Molecular Biology, Bangabandhu Sheikh \\ Mujibur Rahman Agricultural University, Gazipur-1706, Bangladesh, ${ }^{5}$ Department of Biochemistry and Molecular \\ Biology, Bangladesh Agricultural University, Mymensingh-2202, Bangladesh
}

(Received 18 January 2015; Accepted 3 September 2015; First published online 4 November 2015)

Copyright resides with the authors in terms of the Creative Commons Attribution 2.5 South African Licence. See: http://creativecommons.org/licenses/by/2.5/za

Condition of use: The user may copy, distribute, transmit and adapt the work, but must recognise the authors and the South African Journal of Animal Science.

\begin{abstract}
This study was conducted to evaluate the effects of different levels of buckwheat (Fagopyrum esculentum) alone or in combination with chitosan, in broiler diets, on the growth, feed intake and serum lipid profile of broilers. Starting as 10-day olds, 144 Cobb 500 broiler chicks were fed six manually prepared diets containing $0 \%, 10 \%, 20 \%$ or $30 \%$ buckwheat, or $10 \%$ buckwheat supplemented with $250 \mathrm{mg}$ chitosan or 500 $\mathrm{mg}$ chitosan $/ \mathrm{kg}$. The trial lasted 32 days. Buckwheat alone or in combination with chitosan had no effects on the growth and feed intake of the broilers. Until 15 days lipid profiles in blood sera did not change in birds fed buckwheat alone or buckwheat in combination with chitosan. However, at day 30 the inclusion of $10 \%-30 \%$ buckwheat alone and $10 \%$ buckwheat with $250 \mathrm{mg}$ chitosan/ $\mathrm{kg}$ or with $500 \mathrm{mg}$ chitosan $/ \mathrm{kg}$ showed a significant increase in serum HDL-cholesterol concentration and a decrease in total cholesterol, triglycerides and LDL-cholesterol concentrations in the serum compared with the control. This demonstrates for the first time that the feeding of higher levels of buckwheat (20\% or more) alone or lower levels of buckwheat $(10 \%)$ with trace amounts of chitosan influenced the lipid profiles of broilers positively. Because hazardous antibiotics are banned in poultry feed, including of buckwheat with trace amounts of chitosan in broiler diets might be a useful alternative to antibiotics in the poultry industry.
\end{abstract}

\section{Keywords: Buckwheat, cholesterol, feed additive, formulation, triglycerides}

\#Corresponding author. sayed_bmb@yahoo.com

\section{Introduction}

Intensive poultry farming has achieved phenomenal gains in the efficient and economical production of high-quality and safe chicken meat and eggs (Gerber et al., 2007). The use of feed additives has played an important part in this success (Wenk, 2000). Feed additives have been used widely for a long time in the poultry industry as a tool to increase animal performance in terms of growth and feed efficiency (Collington et al., 1990). Therefore, about $80 \%$ of domestic animals received synthetic compounds as medication and as growth promoters (Lee et al., 2001). Antibiotics have been used as feed additives to improve the profitability of poultry production by controlling pathogenic bacteria in the gut mucosa (Castanon, 2007). However, the development of direct antibiotic resistance of pathogens in species that receive the feed (Jang et al., 2007) and indirect resistance to similar antibiotics used in human medicine because of food chain residues (Shea, 2003) led to the banning in many countries including Bangladesh, of all sub-therapeutic levels of growthpromoting antibiotics. Consequently, there is great interest in developing natural alternatives to antibiotic growth promoters that would maintain bird performance and health (Cross et al., 2007). Another major concern of poultry farmers is the price hike in maize-based feeds. Finding cheaper alternatives to food grains such as maize and wheat is an important research topic in the developing of low-cost, sustainable poultry diets.

Meat is an excellent source of high-quality readily digestible protein and of micronutrients (Layrisse et al., 1990; Bender, 1992). On the other hand, hypercholesterolemia is a risk factor for cardiovascular diseases such as atherosclerosis and myocardial infarction, which is a common cause of mortality and 
morbidity in humans (Wald \& Law, 1995; Krieger, 1998). The presence of cholesterol in broiler meat is a main discouraging factor against regular consumption of meat. Many people limit their consumption of broiler meat for fear of elevated serum cholesterol concentrations (Abeywardena, 2003). This has led to underutilization of an excellent source of nutrients in the diet, causing protein malnutrition in many regions of the world, including Bangladesh. One way of lowering broiler meat cholesterol is by incorporating cholesterol-reducing factors in the diet.

Inclusion of the seeds of cultivated plants is an alternative to synthetic antibiotic feed additives (Čabarkapa et al., 2008; Jacob \& Carter, 2008; Leiber et al., 2009; Zhang et al., 2012). A natural cholesterollowering and immunity-enhancing feed supplement is the biopolymer, chitosan (Hirano et al., 1990; Mei, 2011; Jan et al., 2012). The beneficial effects of chitosan as a food supplement include reduced sera cholesterol and triglyceride concentration and improved HDL-cholesterol/total cholesterol ratios (Hirano et al., 1990; Maezaki et al., 1993; Razdan \& Pettersson, 1994; Koide, 1998). At a dose of 3 - 6 g/day, ingested as biscuit by adult healthy human males for two weeks, chitosan decreased total serum cholesterol concentration significantly $(188 \mathrm{mg} / \mathrm{dL}$ to $177 \mathrm{mg} / \mathrm{dL})$ and increased serum HDL-cholesterol concentration (51 mg/dL to $56 \mathrm{mg} / \mathrm{dL}$ ) (Maezaki et al., 1993). When administered to animals, chitosan reduced plasma cholesterol concentrations (Sugano et al., 1980; Hirano et al., 1990; Ikeda et al., 1993). In addition, chitosan has been reported to have antimicrobial properties (Goy et al., 2009). Since total cholesterol lowering effects and HDL-cholesterol increasing effects have been reported in several animal experiments (Hirano et al., 1990), supplementation of chitosan at varying doses in broiler feed may be beneficial to the health of broilers and provide poultry meat with a lowered cholesterol concentration.

Buckwheat (Fagopyrum esculentum Moench) belongs to the Polygonaceae family, which is cultivated in and adapted to marginal lands with harsh environments (Ratan \& Kothiyal, 2011). It is a non-glutinous pseudo-cereal that is consumed as a functional food mainly in China, Japan and Eastern Europe (Edwardson, 1996; Holasova et al., 2002; Zhang et al., 2012). Its starch content is similar to that of cereals, but it contains higher concentrations of amino acids such as lysine, methionine and cystine, which are more typical of legumes (Qian et al., 1998; Zheng et al., 1998). Research suggests that buckwheat has a reasonable feed value, comparable with that of oats (Farell, 1978; Cheeke, 1991). It has medicinal properties such as a high antioxidant activity owing to the presence of bioactive compounds including flavones, flavonoids, phytosterols and myo-inositol (Holasova et al., 2002; Zhang et al., 2012). In addition, it can prevent or cure hypercholesterolemia and hyperglycaemia (Zhang et al., 2007; 2012). This preventative effect may be connected with the contents of dietary fibre and bioactive compounds in buckwheat (He et al., 1995). Pigs that were fed an organic diet containing $25 \%$ buckwheat had slightly higher average daily bodyweight gains than those fed a conventional diet (Koehler, 2002). Therefore, it was suggested to be of interest to test buckwheat as a feed substitute in broiler diets in order to formulate a low-cost poultry diet to promote organic farming (Jacob \& Carter, 2008; Leiber et al., 2009).

Although several reports have focused on the beneficial effects of feeding buckwheat or chitosan to different animal species, including poultry (Jacob \& Carter, 2008; Leiber et al., 2009; Zhang et al., 2012), the effects of including both products in broiler diets have not been investigated. Therefore, the objective of this study was to evaluate the effects of including in broiler diets different levels of buckwheat, with or without trace amounts of chitosan, in terms of bodyweight gain, feed intake and concentrations of serum cholesterol, triglycerides, and high- and low-density lipoproteins in broiler chickens.

\section{Materials and Methods}

The experiment was conducted at the poultry farm of the Hajee Mohammad Danesh Science \& Technology University, Dinajpur, from 27 June 2012 to 7 August 2012. A total of 144 one-day old Cobb 500 broiler chicks were purchased from a local hatchery (CP Bangladesh Ltd., Konabari, Gazipur, Bangladesh). For the first 10 days, the chicks were reared in a brooding house to adjust to environmental conditions. After 10 days, they were randomly assigned to five dietary treatment groups of 24 chicks each. The treatments were: Diets containing $0 \%, 10 \%, 20 \%$ or $30 \%$ buckwheat, or $10 \%$ buckwheat $+250 \mathrm{mg}$ chitosan $/ \mathrm{kg}$ or $10 \%$ buckwheat $+500 \mathrm{mg}$ chitosan $/ \mathrm{kg}$ feed. Each treatment consisted of three replicates of eight birds (four male and four female) in a completely randomized design. The birds were housed on the floor and management routines were similar to those of commercial broiler flocks. Heating was provided by a single gas brooder. The initial temperature was set at $32^{\circ} \mathrm{C}$ and decreased by $2{ }^{\circ} \mathrm{C}$ per week to the final temperature of $20^{\circ} \mathrm{C}$ at the end of experiment. Supplementary heating was provided as required by mobile butane gas heaters and an electric heater.

Chitosan was purchased from Sigma-Aldrich (Shinagawa, Japan). Buckwheat was purchased from Panchagar, a local market in Bangladesh. The buckwheat was coarsely ground with a mechanical grinder. Sundried and ground maize, meat meal, bone meal, rice polish, soybean oilcake, soybean oil and other feed ingredients were obtained from the local market at Dinajpur, Bangladesh. A vitamin/mineral premix was 
purchased from Renata Animal Health Ltd (Dhaka, Bangladesh). The chicks were fed a starter diet from 1 to 10 days, a grower diet from 11 to 20 days and a finisher diet from 21 to 42 days. The feed ingredients were mixed in appropriate ratios and the diets were prepared manually (Tables 1 and 2) to meet the nutrient requirements of broilers (NRC 1994). The composition of grower and finisher rations are presented in Tables 1 and 2. The experimental diets in mash form and drinking water were provided ad libitum.

All the birds were examined without disturbance twice daily for visible physical features such as restlessness, abnormal gait and feeding style. They were vaccinated against Newcastle Disease and Gumboro Disease on the fourth and twentieth days. During the 32 day experimental period, the growth performances of the birds were recorded. Before treatment, bodyweight was recorded for each group of birds. Then bodyweight and feed consumption were recorded weekly. Feed consumption and body weight gain were calculated weekly and feed conversion ratio was calculated at the end of experiment for each

Table 1 Composition of the experimental grower diets fed to broilers

\begin{tabular}{|c|c|c|c|c|c|c|}
\hline \multirow[b]{2}{*}{ Items } & \multicolumn{6}{|c|}{ Dietary level of buckwheat percentage and chitosan, $\mathrm{mg} / \mathrm{kg}$} \\
\hline & $0 \% \mathrm{BW}$ & $10 \% \mathrm{BW}$ & $20 \%$ BW & $30 \% \mathrm{BW}$ & $\begin{array}{c}10 \% \text { BW + } \\
250 \text { mg/kg } \\
\text { chitosan }\end{array}$ & $\begin{array}{c}10 \% \mathrm{BW}+ \\
500 \mathrm{mg} / \mathrm{kg} \\
\text { chitosan }\end{array}$ \\
\hline \multicolumn{7}{|l|}{ Feed Ingredients (\%) } \\
\hline Maize & 52 & 42 & 32 & 22 & 42 & 42 \\
\hline Soybean meal & 21.9 & 21.5 & 21.3 & 21.9 & 21.5 & 21.5 \\
\hline Rice polish & 12 & 12 & 12 & 12 & 12 & 12 \\
\hline Meat and bone meal & 7 & 7 & 7 & 7 & 7 & 7 \\
\hline Soybean oil & 3 & 2.7 & 2.6 & 3 & 2.7 & 2.7 \\
\hline Limestone & 1 & 1 & 1 & 1 & 1 & 1 \\
\hline Di-calcium phosphate & 0.8 & 0.8 & 0.8 & 0.8 & 0.8 & 0.8 \\
\hline Salt & 0.25 & 0.25 & 0.25 & 0.25 & 0.25 & 0.25 \\
\hline Methionine & 0.1 & 0.1 & 0.1 & 0.1 & 0.1 & 0.1 \\
\hline Broiler premix & 0.25 & 0.25 & 0.25 & 0.25 & 0.25 & 0.25 \\
\hline Toxin binder & 0.3 & 0.3 & 0.3 & 0.3 & 0.3 & 0.3 \\
\hline Choline chloride & 0.06 & 0.06 & 0.06 & 0.06 & 0.06 & 0.06 \\
\hline Coccidiostats & 0.02 & 0.02 & 0.02 & 0.02 & 0.02 & 0.02 \\
\hline Lysine & 0.01 & 0.01 & 0.01 & 0.01 & 0.01 & 0.01 \\
\hline Enzyme & 0.05 & 0.05 & 0.05 & 0.05 & 0.05 & 0.05 \\
\hline Growth promoter & 0.05 & 0.05 & 0.05 & 0.05 & 0.05 & 0.05 \\
\hline Buckwheat & 0 & 10 & 20 & 30 & 10 & 10 \\
\hline \multicolumn{7}{|c|}{ Calculated nutrient composition } \\
\hline $\begin{array}{l}\text { Metabolisable energy, } \\
\mathrm{MJ} / \mathrm{kg}\end{array}$ & 13.0 & 13.0 & 13.0 & 13.0 & 13.0 & 13.0 \\
\hline Crude protein, mg/kg & 196 & 196 & 196 & 196 & 196 & 196 \\
\hline Crude fibre, $\mathrm{mg} / \mathrm{kg}$ & 38 & 38 & 38 & 38 & 38 & 38 \\
\hline Calcium, mg/kg & 11.7 & 11.6 & 11.6 & 11.7 & 11.7 & 11.6 \\
\hline Phosphorus, mg/kg & 5.7 & 5.7 & 5.7 & 5.7 & 5.7 & 5.7 \\
\hline Methionine, mg/kg & 4.3 & 4.3 & 4.3 & 4.3 & 4.3 & 4.3 \\
\hline Lysine, mg/kg & 10.5 & 10.6 & 10.6 & 10.5 & 10.5 & 10.6 \\
\hline
\end{tabular}

Added broiler premix (Renata Animal Health Ltd. Bangladesh) at the rate of $250 \mathrm{~g}$ per $100 \mathrm{~kg}$, which contained $4800 \mathrm{IU}$ vitamin $A ; 960$ IU vitamin D; 9.2 mg vitamin $E ; 800$ mg vitamin $K_{3} ; 600$ mg vitamin $B_{1} ; 2$ mg vitamin $B_{2} ; 12$ mg vitamin $B_{3}$; $3.2 \mathrm{mg}$ vitamin $\mathrm{B}_{5} ; 1.8 \mathrm{mg}$ vitamin $\mathrm{B}_{6} ; 2 \mathrm{mg}$ vitamin $\mathrm{B}_{9} ; 0.004 \mathrm{mg}$ vitamin $\mathrm{B}_{12} ; 0.3 \mathrm{mg} \mathrm{Co} ; 2.6 \mathrm{mg} \mathrm{Cu} ; 9.6 \mathrm{mg} \mathrm{Fe} ; 0.6 \mathrm{mg} \mathrm{I}$; 19.2 mg Mn; 16 mg Zn; 0.48 mg Se; 20 mg DL-methionine; 12 mg L-lysine.

Enzyme: phytase (Renata Animal Health Ltd. Bangladesh); growth promoter: probiotic (Renata Animal Health Ltd. Bangladesh). 
treatment. At the end of a week, the residual amount of feed was weighed and subtracted from the known weight of feed at the beginning of week. The result was divided by the total number of birds. Body weight was measured for all birds at the beginning of the experiment, and repeated weekly at the same time of the day. Body weight gain was calculated by subtracting the body weight at the beginning of the week from the body weight at the end of the week. Feed conversion ratio (FCR) was calculated as the amount of feed consumed per unit of bodyweight gain (average feed consumption (g)/average bodyweight gain (g)).

On days 15 and 30 blood was collected from the wing vein of three replicates from each treatment (Islam et al., 2011; Siddiqui et al., 2014) using a sterilized syringe and needle without anticoagulant, and placed in Eppendorf $(1.5 \mathrm{~mL})$ tubes. Within 20 minutes of collection, the blood was centrifuged for 15 minutes at $2500 \mathrm{rpm}$. The supernatant was then carefully collected by micropipette and transferred to Eppendorf tubes. The serum samples were stored at $-15^{\circ} \mathrm{C}$ pending the determination of total cholesterol, HDL-cholesterol and LDL-cholesterol concentrations. At the end of experimental period all birds were sacrificed.

Table 2 Composition of experimental finisher diets ${ }^{1}$ fed to broilers

\begin{tabular}{|c|c|c|c|c|c|c|}
\hline \multirow{2}{*}{ Items } & \multicolumn{6}{|c|}{ Dietary level of buckwheat percentage and chitosan, $\mathrm{mg} / \mathrm{kg}$} \\
\hline & $0 \% \mathrm{BW}$ & $10 \% \mathrm{BW}$ & $20 \%$ BW & $30 \% \mathrm{BW}$ & $\begin{array}{c}10 \% \mathrm{BW}+ \\
250 \mathrm{mg} / \mathrm{kg} \\
\text { chitosan }\end{array}$ & $\begin{array}{c}10 \% \mathrm{BW}+ \\
500 \mathrm{mg} / \mathrm{kg} \\
\text { chitosan }\end{array}$ \\
\hline \multicolumn{7}{|l|}{ Feed Ingredients (\%) } \\
\hline Maize & 55 & 45 & 35 & 25 & 45 & 45 \\
\hline Soybean meal & 20.8 & 20.3 & 20.0 & 20.8 & 20.3 & 20.3 \\
\hline Rice polish & 10.7 & 10.7 & 10.7 & 10.7 & 10.7 & 10.7 \\
\hline Meat and bone meal & 6 & 6 & 6 & 6 & 6 & 6 \\
\hline Soybean oil & 3 & 2.7 & 2.6 & 3 & 2.7 & 2.7 \\
\hline Limestone & 1 & 1 & 1 & 1 & 1 & 1 \\
\hline Di-calcium phosphate & 0.7 & 0.7 & 0.7 & 0.7 & 0.7 & 0.7 \\
\hline Salt & 0.27 & 0.27 & 0.27 & 0.27 & 0.27 & 0.27 \\
\hline Methionine & 0.08 & 0.08 & 0.08 & 0.08 & 0.08 & 0.08 \\
\hline Broiler premix & 0.25 & 0.25 & 0.25 & 0.25 & 0.25 & 0.25 \\
\hline Toxin binder & 0.3 & 0.3 & 0.3 & 0.3 & 0.3 & 0.3 \\
\hline Choline chloride & 0.05 & 0.05 & 0.05 & 0.05 & 0.05 & 0.05 \\
\hline Lysine & 0.02 & 0.02 & 0.02 & 0.02 & 0.02 & 0.02 \\
\hline Enzyme & 0.05 & 0.05 & 0.05 & 0.05 & 0.05 & 0.05 \\
\hline Growth promoter & 0.065 & 0.065 & 0.065 & 0.065 & 0.065 & 0.065 \\
\hline Buckwheat & 0 & 10 & 20 & 30 & 10 & 10 \\
\hline \multicolumn{7}{|c|}{ Calculated nutrient composition } \\
\hline $\begin{array}{l}\text { Metabolisable energy, } \\
\mathrm{MJ} / \mathrm{kg}\end{array}$ & 13.14 & 13.09 & 13.25 & 13.14 & 13.09 & 13.09 \\
\hline Crude protein, mg/kg & 187.6 & 186.9 & 186.6 & 187.6 & 186.9 & 186.9 \\
\hline Crude fibre, $\mathrm{mg} / \mathrm{kg}$ & 37.0 & 37.1 & 37.1 & 37.0 & 37.1 & 37.1 \\
\hline Calcium, mg/kg & 10.7 & 10.7 & 10.8 & 10.7 & 10.7 & 10.7 \\
\hline Phosphorus, mg/kg & 5.0 & 5.2 & 5.2 & 5.0 & 5.2 & 5.2 \\
\hline Methionine, $\mathrm{mg} / \mathrm{kg}$ & 4 & 4 & 4 & 4 & 4 & 4 \\
\hline Lysine, mg/kg & 10 & 10 & 10 & 10 & 10 & 10 \\
\hline
\end{tabular}

\footnotetext{
${ }^{1}$ Vitamin / mineral premix as presented in Table 1.
} 
Data were analysed using the analysis of variance technique through the MSTATC program according to Kuehl (1994). The means were compared with Duncan's multiple range test. Statements of statistical significance were based on $P<0.05$.

\section{Results}

The effect of the experimental diet on the growth performance of the Cobb 500 broilers is shown in Table 3. Although average feed intake (g) per bird per week varied among the treatments, substitution of different levels of buckwheat and buckwheat plus chitosan supplementation had no statistically significant effect on body weight gain (Tables 3). This was evident throughout the four week growth period (Table 4). Total feed consumption was not significant different $(P>0.05)$ between treatment, and consequently also not between FCRs over the experimental period. Feed intake was low in the first week, but higher in the second, third and fourth weeks in the $10 \%$ buckwheat-substituted diet. In general, feed intake varied slightly in the first week, second and fourth week, but in the third week, it was statistically similar.

Table 3 Effects of varying levels of buckwheat (BW) and buckwheat with chitosan on growth performances of broiler chickens fed on experimental diets

\begin{tabular}{|c|c|c|c|c|c|c|}
\hline \multirow[b]{2}{*}{ Parameters } & \multicolumn{6}{|c|}{ Treatments } \\
\hline & $0 \% \mathrm{BW}$ & $10 \% \mathrm{BW}$ & $20 \% \mathrm{BW}$ & $30 \% \mathrm{BW}$ & $\begin{array}{c}10 \% \text { BW + } 250 \mathrm{mg} \\
\text { chitosan/kg }\end{array}$ & $\begin{array}{c}10 \% \text { BW + } 300 \mathrm{mg} \\
\text { chitosan } / \mathrm{kg}\end{array}$ \\
\hline *Weight gain (g) & 1076 & 957 & 921 & 1096 & 1053 & 1075 \\
\hline Total feed intake (g) & 2868 & 3088 & 2898 & 2892 & 2780 & 2954 \\
\hline **FCR & 2.66 & 3.22 & 3.14 & 2.63 & 2.64 & 2.74 \\
\hline
\end{tabular}

*Weight gain: final body - initial body weight.

** FCR: feed conversion ratio.

Table 4 Effects of varying levels of buckwheat (BW) and buckwheat with chitosan on average body weight gain and feed intake of broiler chickens fed the experimental diets ( $\mathrm{g} / \mathrm{bird} / \mathrm{week})$

\begin{tabular}{|c|c|c|c|c|c|c|}
\hline \multirow{2}{*}{ Parameters } & \multicolumn{6}{|c|}{ Treatments } \\
\hline & 0\% BW & $10 \% \mathrm{BW}$ & $20 \%$ BW & $30 \% \mathrm{BW}$ & $\begin{array}{c}10 \% \mathrm{BW}+250 \mathrm{mg} \\
\text { chitosan } / \mathrm{kg}\end{array}$ & $\begin{array}{c}10 \% \text { BW + } 300 \mathrm{mg} \\
\text { chitosan } / \mathrm{kg}\end{array}$ \\
\hline \multicolumn{7}{|c|}{ Body weight gain (g/bird/week) } \\
\hline First week & 210.5 & 204.2 & 222.9 & 233.4 & 225.0 & 231.3 \\
\hline Second week & 475.0 & 494.0 & 504.2 & 520.8 & 487.5 & 495.8 \\
\hline Third week & 791.7 & 743.5 & 791.7 & 812.5 & 804.2 & 851.8 \\
\hline Fourth week & 1175 & 1053 & 1013 & 1182 & 1154 & 1170 \\
\hline \multicolumn{7}{|c|}{ Feed intake (g/bird/week) } \\
\hline First week & $43.36^{\mathrm{ab}}$ & $40.51^{b}$ & $43.82^{\mathrm{ab}}$ & $43.28^{\mathrm{ab}}$ & $41.18^{\mathrm{ab}}$ & $46.50^{\mathrm{a}}$ \\
\hline Second week & $82.26^{b}$ & $91.01^{a}$ & $81.65^{b}$ & $81.49^{b}$ & $79.80^{b}$ & $82.50^{\mathrm{b}}$ \\
\hline Third week & 131.6 & 133.3 & 131.0 & 131.0 & 127.1 & 135.4 \\
\hline Fourth week & $152.5^{\mathrm{ab}}$ & $176.3^{a}$ & $157.6^{\mathrm{ab}}$ & $157.4^{\mathrm{ab}}$ & $149.0^{b}$ & $157.6^{\mathrm{ab}}$ \\
\hline
\end{tabular}

Means with different superscripts within a row differ significantly $(P<0.05)$.

Table 5 shows the percentage increase or decrease of total cholesterol, triglycerides, LDL-cholesterol and HDL-cholesterol concentrations in the blood sera of broilers fed varying levels of buckwheat and chitosan-supplemented diets. At day 30, total serum cholesterol concentration was significantly lower ( $P$ $<0.05$ ) in broilers that were fed $10 \%$ buckwheat plus $500 \mathrm{mg}$ chitosan/kg compared with day 15 (Figure 1). Although total cholesterol concentration decreased in almost all treatments at day 30, the decrease was not 
statistically significant compared with the values recorded on day 15. Irrespective of day, serum triglyceride concentrations were significantly reduced $(P<0.05)$ in the birds receiving the $30 \%$ buckwheat diet as well as the $10 \%$ buckwheat plus $500 \mathrm{mg}$ chitosan (Figure 2). Lower levels (up to 20\%) of buckwheat alone had no effect on this parameter. Although feeding treatments up to 15 days had no effect on serum LDL-cholesterol concentrations, feeding $30 \%$ buckwheat and $10 \%$ buckwheat plus $250 \mathrm{mg}$ and $10 \%$ buckwheat plus $500 \mathrm{mg}$ chitosan $/ \mathrm{kg}$ feed for 30 days reduced serum LDL-cholesterol concentration in the broilers significantly $(P$ $<0.05$ ) (Figure 3 and Table 5). On the other hand, serum HDL-cholesterol concentration remained unchanged up to 15 days of feeding treatment with varying levels of buckwheat and buckwheat plus chitosan. Interestingly, serum HDL-cholesterol concentration increased in the treatment of buckwheat alone and in combination with chitosan at 30 day (Figure 4 and Table 5). The highest serum HDL-cholesterol concentration was recorded in the broilers that received the diet containing $30 \%$ buckwheat, which was statistically similar to that of the treatments containing $10 \%$ buckwheat plus $250 \mathrm{mg} / \mathrm{kg}$ and $10 \%$ buckwheat plus $500 \mathrm{mg} / \mathrm{kg}$ of chitosan (Table 5). It appears from Table 5 that buckwheat alone at $20 \%-30 \%$, and $10 \%$ buckwheat in combination with $250 \mathrm{mg} / \mathrm{kg}$ and with $500 \mathrm{mg} / \mathrm{kg}$ of chitosan in the diet increased serum HDLcholesterol (up to 191\%) and decreased total sera cholesterol, triglycerides and LDL-cholesterol concentrations in the broilers (Table 5). At day 15, total cholesterol concentrations increased by $13.8 \%, 6.4 \%$ and $2.1 \%$ in birds fed $10 \%$ buckwheat, $10 \%$ buckwheat with $250 \mathrm{mg}$ chitosan $/ \mathrm{kg}$, and $10 \%$ buckwheat with $500 \mathrm{mg}$ chitosan/ $\mathrm{kg}$, respectively, compared to the control. However, cholesterol concentration decreased by $5.70 \%$ and $2.37 \%$ compared with the control when $20 \%$ and $30 \%$ buckwheat were included in the diet, respectively. It appears that both chitosan-supplemented diets decreased serum cholesterol concentration by up to $8.43 \%$ compared with the control. Serum triglyceride concentrations of broiler chickens decreased in general in all dietary treatments at day 15, except the $10 \%$ buckwheat diet. At day 30 , serum triglyceride concentrations decreased by $29 \%, 20 \%$ and $33 \%$ in diets containing $30 \%$ buckwheat, $10 \%$ buckwheat with $250 \mathrm{mg} / \mathrm{kg}$, and $10 \%$ buckwheat with $500 \mathrm{mg} / \mathrm{kg}$ of chitosan, respectively. LDL-cholesterol concentration had decreased up to $96 \%$ at day 30 in the treatments containing 30\% buckwheat or $10 \%$ buckwheat with $250 \mathrm{mg}$ or $500 \mathrm{mg}$ chitosan $/ \mathrm{kg}$.

Table 5 Percentage increase or decrease from control of total cholesterol, triglyceride, LDL-cholesterol and HDL-cholesterol concentrations in serum of broiler chickens at 15 and 30 days feeding varying levels of buckwheat (BW) and buckwheat with chitosan

\begin{tabular}{lcccccccc}
\hline & \multicolumn{7}{c}{ Percentage increase or decrease over control } \\
\cline { 2 - 9 } Treatments & \multicolumn{2}{c}{ Total cholesterol } & \multicolumn{2}{c}{ Triglyceride } & \multicolumn{2}{c}{ LDL-cholesterol } & \multicolumn{2}{c}{ HDL-cholesterol } \\
& Day 15 & Day 30 & Day 15 & Day 30 & Day 15 & Day 30 & Day 15 & Day 30 \\
\hline Control diet & 0 & 0 & 0 & 0 & 0 & 0 & 0 & 0 \\
$10 \%$ BW & +13.8 & +11.6 & +1.15 & +10.38 & +17.1 & -19.3 & +13.7 & +68.2 \\
$20 \%$ BW & -5.70 & +5.67 & -8.01 & +0.97 & -1.78 & -32.6 & -29.6 & +73.5 \\
$30 \%$ BW & -2.37 & +1.71 & -26.7 & -29.4 & +3.86 & -96.2 & +2.57 & +191.7 \\
$10 \%$ BW + 250 mg chitosan & +6.40 & -7.91 & -2.21 & -19.7 & +9.99 & -96.2 & -4.87 & +150.0 \\
$10 \%$ BW+ 500 mg chitosan & +2.12 & -8.43 & -16.5 & -33.4 & +3.92 & -95.1 & +29.8 & +157.0 \\
\hline
\end{tabular}

\section{Discussion}

This study demonstrated that, irrespective of level, buckwheat on its own or in combination with chitosan had no adverse effects on the growth and feed intake of broilers. This report, for the first time, has demonstrated that feeding buckwheat $(10 \%-30 \%)$ alone and at $10 \%$ inclusion plus chitosan at $250 \mathrm{mg} / \mathrm{kg}$ positively influenced the lipid profiles of broilers. According to Jan et al. (2012) chitosan showed positive effects on meat quality, and enhanced immunity, disease control and mortality in broilers. In addition, several studies suggested that buckwheat has a reasonable feed value, high antioxidant activity and contains lysine with other essential amino acids and bioorganic compounds which reduce mortality, and blood sera cholesterol, triglycerides, LDL and HDL concentrations (Myer \& Meinke 1994; Holasova et al., 2002; Zhang et al., 2012). Furthermore, enzyme analyses revealed that serum aspartate transaminase (AST) and serum alanine transaminase (ALT) activities were significantly lower in broilers fed $10 \%$ buckwheat with trace 


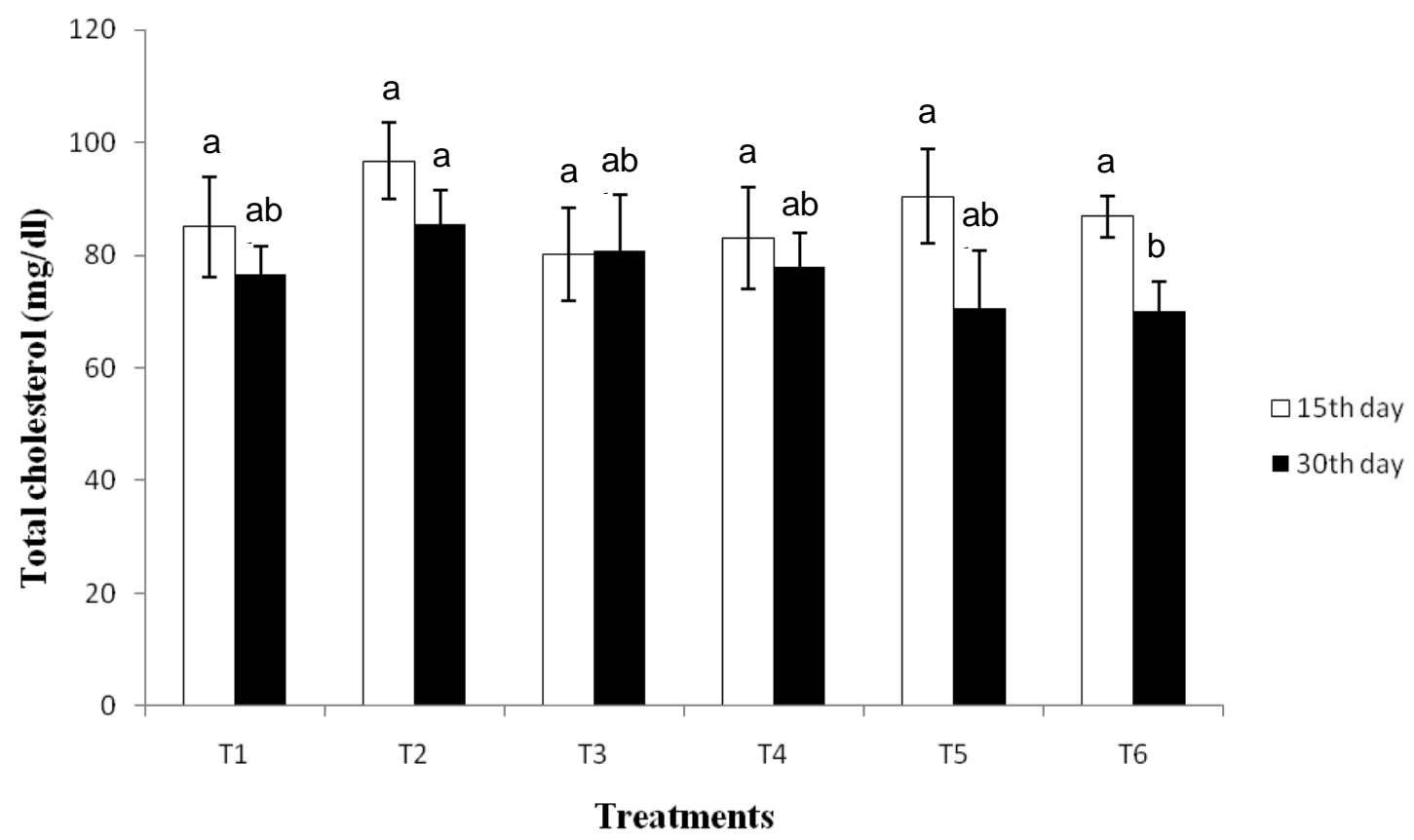

Figure 1 Effects of varying levels of buckwheat seed powder or buckwheat with chitosan supplementation in diets on serum cholesterol $(\mathrm{mg} / \mathrm{dL})$ of broiler chicks at 15 days and 30 days feeding.

The data comprise the average \pm standard error of at least three replications, each of which has eight birds. Data points bearing different letters are significantly different at $P<0.005$. $\mathrm{T}_{1}$ : control ( $0 \%$ buckwheat and $0 \%$ chitosan); $\mathrm{T}_{2}: 10 \%$ buckwheat; $\mathrm{T}_{3}: 20 \%$ buckwheat; $\mathrm{T}_{4}: 30 \%$ buckwheat seed; $\mathrm{T}_{5}: 10 \%$ buckwheat $+250 \mathrm{mg} / \mathrm{kg}$ chitosan; and $\mathrm{T}_{6}: 10 \%$ buckwheat $+500 \mathrm{mg}$ chitosan $/ \mathrm{kg}$. Same colour bars showing same letter do not differ significantly $(P>0.05)$

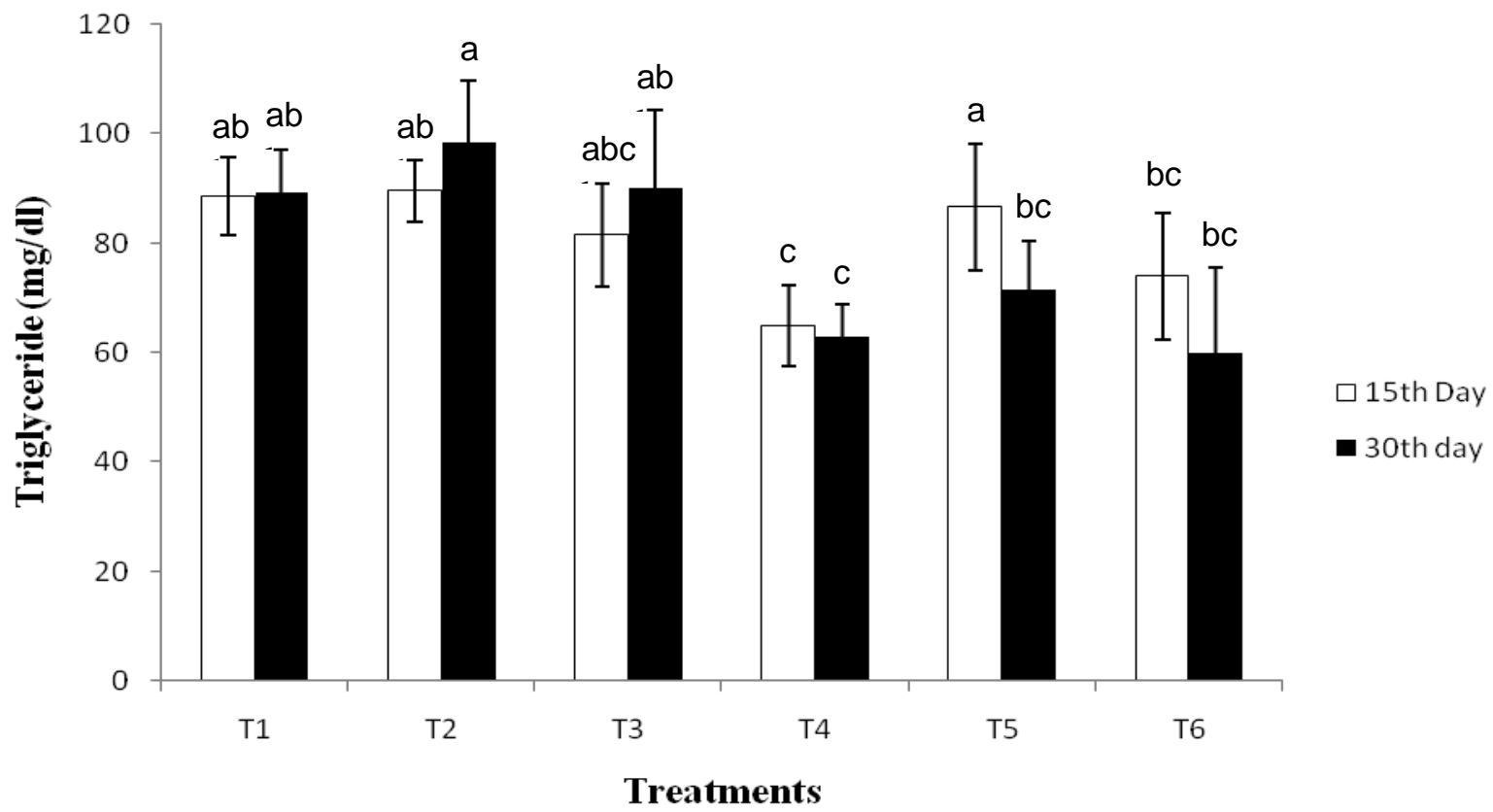

Figure 2 Effects of varying levels of buckwheat seed powder or buckwheat with chitosan supplementation in diets on serum triglycerides $(\mathrm{mg} / \mathrm{dL})$ concentration of broiler chicks at 15 days and 30 days feeding.

The data comprise the average \pm standard error of at least three replications, each of which has eight birds. Data points bearing different letters are significantly different at $P<0.005$. $T_{1}$ : control; $T_{2}$ : control $+10 \%$ buckwheat seed; $T_{3}$ : control + $20 \%$ buckwheat seed; $\mathrm{T}_{4}$ : control $+30 \%$ buckwheat seed; $\mathrm{T}_{5}$ : control $+10 \%$ buckwheat seed $+250 \mathrm{mg}$ chitosan $/ \mathrm{kg}$ and $\mathrm{T}_{6}$ : control $+10 \%$ buckwheat seed $+500 \mathrm{mg}$ chitosan $/ \mathrm{kg}$. Same colour bars showing same letter do not differ significantly $(P<0.05)$ 


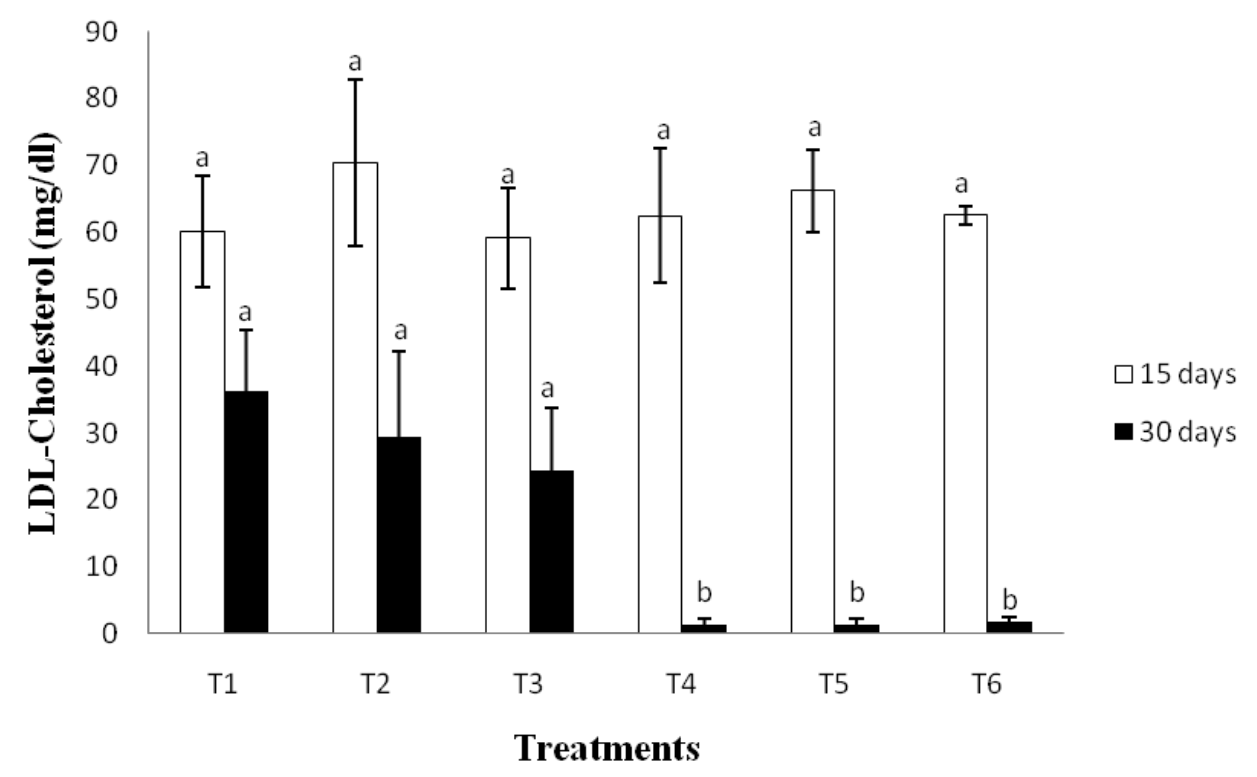

Figure 3 Effects of varying levels of buckwheat seed powder or buckwheat with chitosan supplementation in diets on serum LDL-cholesterol $(\mathrm{mg} / \mathrm{dL})$ of broiler chicks at 15 days and 30 days of feeding

The data comprise the average \pm standard error of at least three replications, each of which has eight birds. Data points bearing different letters are significantly different at $P<0.005$. $\mathrm{T}_{1}$ : control; $\mathrm{T}_{2}$ : control $+10 \%$ buckwheat seed; $\mathrm{T}_{3}$ : control $+20 \%$ buckwheat seed; $\mathrm{T}_{4}$ : control $+30 \%$ buckwheat seed; $\mathrm{T}_{5}$ : control $+10 \%$ buckwheat seed $+250 \mathrm{mg}$ chitosan $/ \mathrm{kg}$ and $\mathrm{T}_{6}$ : control $+10 \%$ buckwheat seed $+500 \mathrm{mg}$ chitosan $/ \mathrm{kg}$. Same colour bars showing same letter do not differ significantly $(P<0.05)$,

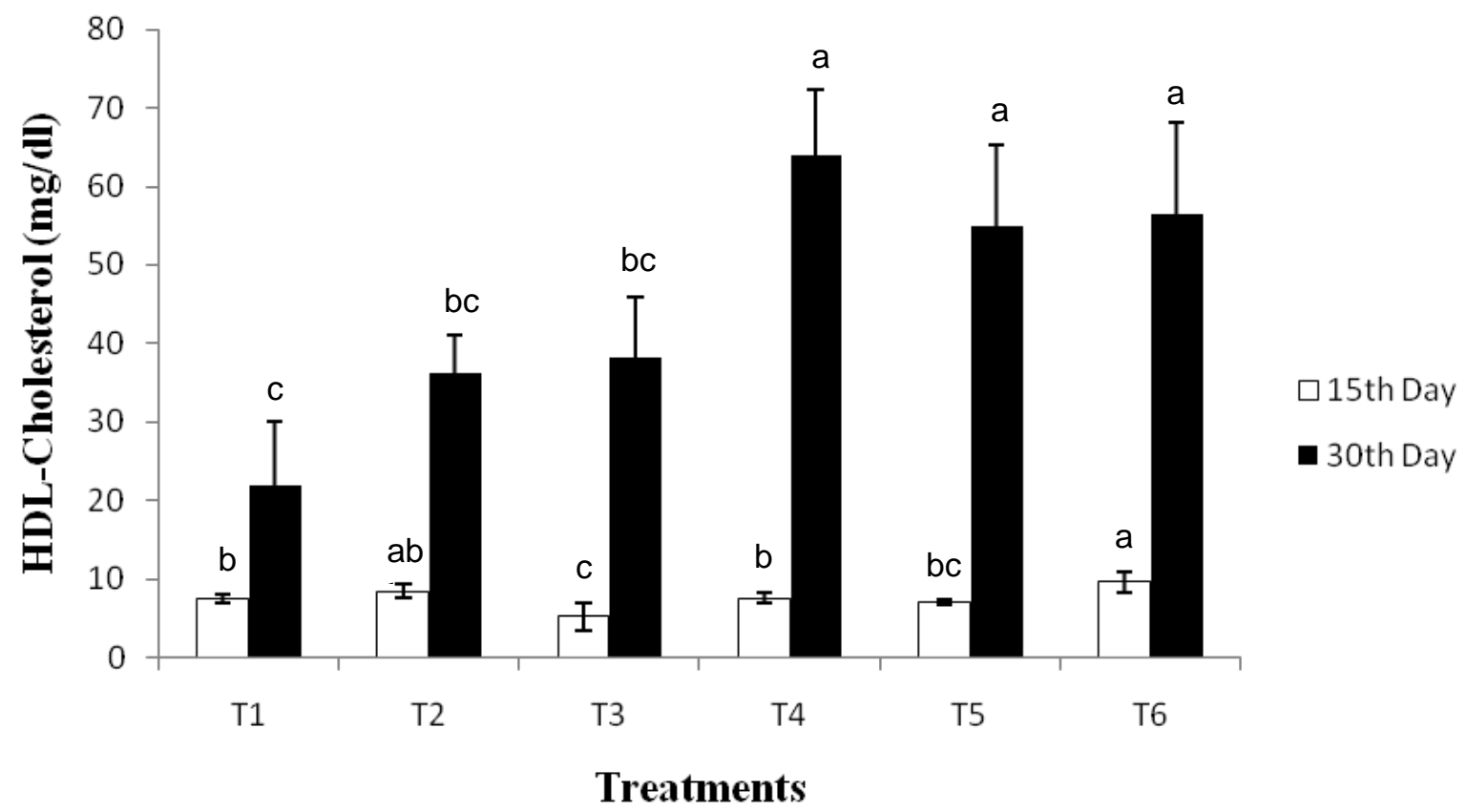

Figure 4 Effects of varying levels of buckwheat seed powder or buckwheat with chitosan supplementation in diets on serum HDL-cholesterol $(\mathrm{mg} / \mathrm{dL})$ of broiler chicks at 15 days and 30 days of feeding.

The data comprise the average \pm standard error of at least three replications, each of which has eight birds. Data points bearing different letters are significantly different at $P<0.005$. $\mathrm{T}_{1}$ : control; $\mathrm{T}_{2}$ : control $+10 \%$ buckwheat seed; $\mathrm{T}_{3}$ : control $+20 \%$ buckwheat seed; $\mathrm{T}_{4}$ : control $+30 \%$ buckwheat seed; $\mathrm{T}_{5}$ : control $+10 \%$ buckwheat seed $+250 \mathrm{mg}$ chitosan $/ \mathrm{kg}$ and $\mathrm{T}_{6}$ : control $+10 \%$ buckwheat seed $+500 \mathrm{mg}$ chitosan $/ \mathrm{kg}$. Same colour bars showing same letter do not differ significantly $(P<0.05)$. 
amounts $(250-500 \mathrm{mg} / \mathrm{kg})$ of chitosan compared with the control, indicating that the liver function of the treated birds was better than those of the untreated control (data not shown). Although the mechanisms of the positive influence of a higher level of buckwheat on the lipid profiles of the birds are difficult to explain from the current data, they might be associated with the effects of bioactive compounds in the seeds of buckwheat that affected the lipid profile of the birds (Holacova, et al., 2002; Zhang et al., 2012). Antioxidant activity and lipid profile-changing activities of buckwheat were both found in earlier studies (He et al., 1995; Xiping \& Xiangiong, 1995; Lin et al., 1998; Holasova et al., 2002; Gang et al., 2012; Zhang et al., 2012). For example, Xiping \& Xiangiong (1995) observed that the inclusion of buckwheat in human diets significantly decreased serum concentrations of triglycerides, total cholesterol and low-density lipoprotein (LDL), and increased the concentration of beneficial high-density lipoprotein (HDL). In another study, hyperlipemia patients showed lower serum triglycerides and cholesterol concentrations after they began to eat tartary buckwheat flour and stopped taking medicine against hyperlipemia (Lin et al., 1998). Buckwheat protein product showed strong hypocholesterolemic activity in rats fed a cholesterol-enriched diet (Kayshita et al., 1997; Zhang et al., 2012). The mechanism of these effects has still to be clarified, but could be related to the low digestibility of buckwheat protein, its good nutritional value, or specific effects of phytochemicals in the seeds of buckwheat such as rutin (Halosova et al., 2002). As the price of organic maize continues to increase, the lower price for buckwheat may make it an attractive economical replacement in organic broiler diets (Jacob \& Carter, 2008). Therefore, buckwheat could be regarded as an alternative to wheat or maize in broiler diets, which could include beneficial side effects for sustainable feed production (Jacob \& Carter 2008; Leiber et al., 2009).

Although positive effects have been reported on poultry consuming chitosan or buckwheat alone (Hirano et al., 1990; Razdan \& Pettersson, 1994; Kondo \& Osad 1996; Tanaka et al., 1997; Mei 2011), this is the first report on positive lipid profile-changing effects of buckwheat with trace amounts of chitosan. Several animal studies have confirmed that supplementing chitosan at up to $50 \mathrm{~g} / \mathrm{kg}$ in feed has no negative effects on the growth and feed intake of the treated animals (Kobayashi et al., 2002; 2006; Han et al., 2007; Hossain \& Blair, 2007; Khambualai et al., 2009; Yan \& Kim, 2011). Results in the present study agree with those findings as no detrimental effects of chitosan at up to $500 \mathrm{mg} / \mathrm{kg}$ were recorded. Cholesterol-lowering effects of chitosan were observed by earlier investigators (Sugano et al., 1980; Hirano et al., 1990; Ikeda et al., 1993; Maezaki et al., 1993; Koide, 1998;). However, lower bodyweights and feed intakes in broilers have been reported when higher doses of chitosan were supplied (Razdan et al., 1997). Chitosan is known to cause high viscosity in the gastrointestinal tract owing to its high water-holding capacity (Edwards, 1990; Razdan \& Pettersson, 1996). In another study, $15 \mathrm{~g}$ dietary chitosan/kg decreased ileal fat digestibility (Fukada et al., 1991). Broiler chickens fed on diets containing $0.6 \mathrm{~g}$ chitosan/kg showed a $138 \mathrm{~g}$ greater bodyweight gain than control birds (Khambualai et al., 2008).

The antimicrobial and immunity enhancement activities of chitosan and buckwheat have been reported by several investigators (Razdon \& Petterson, 1995; Tanaka et al., 1997; Cushnie \& Lamb, 2005). Thus buckwheat with trace amounts of chitosan offers a potential alternative to wheat and maize in broiler diets, which could possibly include beneficial side effects for sustainable feed production on marginal lands with harsh environments.

\section{Conclusion}

This study demonstrated that at buckwheat inclusions of up to $30 \%$ in a diet, and $10 \%$ buckwheat with trace amounts of chitosan $(250 \mathrm{mg} / \mathrm{kg}$ and $500 \mathrm{mg} / \mathrm{kg}$ ) significantly increased serum HDL-cholesterol concentration and decreased serum total cholesterol, triglycerides and LDL-cholesterol concentrations in broilers without affecting the growth and feed intake of the birds. In Bangladesh, buckwheat is cheaper than maize because of its lower production costs, compared with Europe. Generally, in Bangladesh, farmers cultivate buckwheat with less input of labour and fertilizer. Because buckwheat is a low-cost alternative to maize, supplementing the grain with trace amounts of chitosan might be useful in preparing an alternative low-cost feed formulation for the poultry industry. Because the use of hazardous antibiotics in poultry feed is banned in many countries, including Bangladesh, a combination of buckwheat and chitosan might be an alternative. Further research is warranted to assess the molecular mechanisms involved in the beneficial effects of buckwheat and chitosan shown in the present study before large-scale practical use in the poultry industry.

\section{Acknowledgements}

The authors are grateful for partial financial support from the University of Grants Commission, Bangladesh (to MAS), and World Bank through the sub-project (CP \# 2071) of HEQEP to the Department of Biotechnology of Bangabandhu Sheikh Mujibur Rahman Agricultural University, Bangladesh. 


\section{References}

Abeywardena, M.Y., 2003. Dietary fats, carbohydrates and vascular disease: Sri Lankan perspectives. Atheroscler. 171, 157-161.

Bender, A., 1992. Meat and meat products in human nutrition in developing countries. Food Nutr. Pap. 53, 1-88.

Cabarkapa, I.S., Sedej, I.J., Sakac, M.B., Saric, L.C. \& Plavsic, D.V., 2008. Antimicrobial activity of buckwheat (Fagopyrum esculentums Moench) hulls extract. Food Process. Qual. Saf. 4, 159-163.

Cheeke, P.R., 1991. Applied Animal Nutrition: Feeds and Feeding. MacMillan Publishing Co., New York, N.Y., USA.

Castanon, J.I.R., 2007. Review: History of the use of antibiotic as growth promoters in European poultry feeds. Poult. Sci. 86, 2466-2471.

Collington, G.K., Park, D.S. \& Armstrong, D.G., 1990. The influence of inclusion of both an antibiotic and a probiotic in the diet on the development of digestive enzyme activity in the pig. Br. J. Nutr. 64, 59-70.

Cross, D.E., McDevitt, R.M., Hillman, K. \& Acamovic, T., 2007. The effect of herbs and their associated essential oils on performance, dietary digestibility and gut microflora in chickens from 7 to 28 days of age. Br. Poult. Sci. 48, 496-506.

Cushnie, T.P.T. \& Lamb, A.J., 2005. Antimicrobial activity of flavonoids. Int. J. Antimicrob. Ag. 26, 343-356.

Edwards, C., 1990. Mechanisms of action on dietary fiber on small intestinal absorption and motility, New Dev. Diet. Fiber. 270, 95-104.

Edwardson, S., 1996. Buckwheat: pseudocereal and nutraceutical. In: Progress in New Crops. Ed: Janick, J., ASHS Press, Alexandria, Virginia. pp. 195-207.

Farrel, D.J., 1978. A nutritional evaluation of buckwheat (Fagopyrum esculentum). Anim. Feed Sci. Technol. 3, 95-108.

Gang, Z., Lian-xin, P., Shu, W., Yi-bing, H. \& Liang, Z., 2012. HPLC-fingerprint-antioxidant properties study of buckwheat. J. Integrat. Agric. 11, 1111-1118.

Gerber, P., Opio, C. \& Steinfeld, H., 2007. Poultry production and the environment- A review. Poultry in 21st Century: Avian Influenza and Beyond, International Poultry Conference, Bangkok, Thailand.

Goy, R.C., De Britto, D. \& Assis, O.B.G., 2009. A review of the antimicrobial activity of chitosan. Polimeros. 19, 241-247.

Han, K.N., Kwon, I.K., Lohakare, J.D., Heo, S. \& Chae, B.J., 2007. Chitooligosaccharides as an alternative to antimicrobials in improving performance, digestibility and microbial ecology of the gut in weanling pigs. Asian Austral. J. Anim. Sci. 20, 556-562.

He, J., Klag, M.J., Whelton, M.J., Mo, J.P., Chen, J.Y., Qian, M.C., Mo, P.S. \& He, G.S., 1995. Oats and buckwheat intakes and cardiovascular disease risk factors in an ethnic minority in China. Am. J. Clin. Nutr. 61, 366-372.

Holasova, M., Fiedlerova, V., Smrcinova, H., Orsak, M., Lachman, J. \& Vavreinova, S., 2002. Buckwheat the source of antioxidant activity in functional foods. Food Res. Int. 35, 207-2011.

Hossain, S.M. \& Blair, R., 2007. Chitin utilization by broilers and its effect on body composition and blood metabolites. Br. Poult. Sci. 48, 33-38.

Ikeda, I., Sugano, M., Yoshida, K., Sasaki, E., Iwamoto, Y. \& Hatano, K., 1993. Effects of chitosan hydrolysates on lipid absorption and on serum and liver lipid concentrations in rats. J. Agric. Food Chem. 41, 431-435.

Islam, M.T., Selim, A.S.M., Sayed, M.A., Khatun, M.A., Siddiqui, M.N., Alam, M.S. \& Hossain, M.A., 2011. Nigella sativa L. supplemented diet decreases egg cholesterol content and suppresses harmful intestinal bacteria in laying hens. J. Anim. Feed Sci. 20, 587-598.

Jacob, J.P. \& Carter, C.A., 2008. Inclusion of buckwheat in organic broiler diets. J. Appl. Poult. Res. 17, $522-528$

Jan, S.S., Liu, D.C., Dong, X.Y., Hu, Y.M. \& Chen, J.D., 2012. Effect of chitosan and its derivative added to water on immunological enhancement and disease control. Immunotherapy 4, 697-701.

Jang, I.S., Ko, Y.H., Kang, S.Y. \& Lee, C.Y., 2007. Effect of a commercial essential oil on growth performance, digestive enzyme activity and intestinal microflora population in broiler chickens. Anim. Feed Sci. Technol. 134, 304-315.

Kayashita, J., Shimaoka, I., Nakajoh, M., Yamazaki, M. \& Norihisa, K., 1997. Consumption of buckwheat protein lowers plasma cholesterol and raises fecal neutral sterols in cholesterol-fed rats because of its low digestibility. J. Nutr. 127, 1395-1400.

Khambualai, O., Yamauchi, K., Tangtaweewipat, S. \& Cheva-Isarakul, B., 2008. Effects of dietary chitosan diets on growth performance in broiler chickens. J. Poult. Sci. 45, 206-209.

Khambualai, O., Yamauchi, K., Tangtaweewipat, S. \& Cheva-Isarakul, B., 2009. Growth performance and intestinal histology in broiler chickens fed with dietary chitosan, Br. Poult. Sci. 50, 592-597. 
Kobayashi, S., Terashima, Y. \& Itoh, H., 2002. Effects of dietary chitosan on fat deposition and lipase activity in digesta in broiler chickens. Br. Poult. Sc. 43, 270-273.

Kobayashi, S., Terashima, Y. \& Itoh, H., 2006. The effects of dietary chitosan on liver lipid concentration in broiler chickens treated with propylthiouracil. J. Poult. Sci. 43, 162-166.

Koehler, B., 2002. Organic hog production using several organic feed diets. Research report. Southwest Research and Outreach Center (SWROC) of the University of Minnesota, USA.

Koide, S.S., 1998. Chitin-chitosan: Properties, benefits and risks. Nutr. Res. 18, 1091-1101.

Kondo, H. \& Osada, A., 1996. Influence of dietary fiber on the bioavailability of zinc in rats. Biomed. Environ. Sci. 9, 204-208.

Krieger, M., 1998. The "best" of cholesterols, the "worst" of cholesterols: A tale of two receptors. Proc. Natl. Acad. Sci. USA. 95, 4077-4080.

Kuehl, R.O., 1994. Statistical principles of research design and analysis. Duxbury Press, Belmont, CA. pp. 686.

Layrisse, M., Martinez-Torres, C., Mendez-Costellaro, H., Taylor, P., Fossi, M., Lopez de Blanco, M., Landaeta-Jimenez, M., Jaffe, W., Leets, I., Tropper, E., Garcia-Casal, M. \& Ramirez, J., 1990. Relationship between iron bioavailability from diets and the prevalence of iron deficiency. Food Nutr. Bull. 12, 301-309.

Leiber, F., Messikommer, R. \& Wenke, C., 2009. Buckwheat: a feed for broiler chicken? Agrarforschung 16, 448-453.

Lin, L.Y., Peng, C.C., Yang, Y.L. \& Peng, R.Y., 2008. Optimization of bioactive compounds in buckwheat sprouts and their effect on blood cholesterol in hamsters. J. Agric. Food Chem. 56, 1216-1223.

Maezaki, Y., Tsuji, K., Nakagawa, Y., Kawai, Y., Akimoto, M., Tsugita, T., Takekawa, W., Terada, A., Hara, A. \& Mitsuoka, T., 1993. Hypocholesterolemic effect of chitosan in adult males. Biosci. Biotech. Biochem. 57, 1439-1444.

Mei, L., 2011. Effect of chitosan on meat quality in broilers. Dongbei Nongye Daxue Xuebao 42, 25-28.

Myers, R.L. \& Meinke, L.J., 1994. Buckwheat: A multi-purpose, short-season alternative. Publication G4306. University of Missouri, Columbia.

Qian, J., Rayas-Duarte, P. \& Grant, L., 1998. Partial characterization of buckwheat (Fagopyrum esculentum) starch. Cereal Chem. 75, 365-373.

Ratan, P. \& Kothiyal, P., 2011. Fagopyrum esculentum Moench (common buckwheat) edible plant of Himalayas: A Review. Asian J. Pharm. Life Sci. 1 (4), 426-442.

Razdan, A. \& Pettersson, O., 1994. Effect of chitin and chitosan on nutrient digestibility and plasma lipid concentrations in broiler chickens. Br. J. Nutr. 72, 277-288.

Razdan, A. \& Pettersson, O., 1996. Hypolipidaemic, gastrointestinal and related responses of broiler chickens to chitosans of different viscosity. Br. J. Nutr. 76, 387-397.

Razdan, A., Pettersson, D. \& Pettersson, J., 1997. Broiler chicken body weights, feed intakes, plasma lipid and small-intestinal bile acid concentrations in response to feeding of chitosan and pectin. Br. J. Nutr. 78, 283-291.

Shea, K.M., 2003. Antibiotic resistance: What is the impact of agricultural uses of antibiotics on children's health? Pediatre. 112, 253-258.

Siddiqui, M.N., Islam, M.T., Sayed, M.A. \& Hossain, M.A., 2015. Effect of dietary supplementation of acetone extracts of Nigella sativa seeds on serum cholesterol and pathogenic intestinal bacterial count in broilers. J. Anim. Plant Sci. 25 (2), 372-379.

Sugano, M., Fujikawa, T., Hiratsuji, Y., Nakashma, K., Fukuda, N. \& Hasegawa, Y., 1980. A novel use of chitosan as a hypocholesterolemic agent in rats. Am. J. Clin. Nutr. 33, 787-793.

Tanaka, Y., Tanioka, S., Tanaka, M., Tanigawa, T., Kitamura, Y., Minami, S., Okamoto, Y., Miyashita, M. \& Nanno, M., 1997. Effects of chitin and chitosan particles on BALB/c mice by oral and parenteral administration. Biomater. 18, 591-595.

Wald, N.J. \& Law, M.R., 1995. Serum cholesterol and ischaemic heart disease. Atheroscler. 118, 1-5.

Wenk, C., 2000. Recent advances in animal feed additives such as metabolic modifiers, antimicrobial agents, probiotics, enzymes and highly available minerals: Review. Asian Austral. J. Anim. Sci. 13, 8695.

Wieslander, G., Fabjan, N., Vogrincic, M., Kreft, I., Janson, C., Spetz-Nystrom, U., Vombergar, B., Tagesson, C., Leanderson, P. \& Norback, D., 2011. Eating buckwheat cookies is associated with the reduction in serum levels of myeloperoxidase and cholesterol: A double blind crossover study in day-care centre staffs. Tohoku J. Exp. Med. 225, 123-130.

Xiping Land Xianqiong, F., 1995. Clinical effects of tartary buckwheat on senile hyperlipemia. Curr. Adv. Buckwheat Res. 2, 947-950. 
Yan, L. \& Kim, H.I., 2011. Evaluation of dietary supplementation delta-aminolevulinic acid and chitooligosaccharide on growth performance, nutrient digestibility, blood characteristics and fecal microbial shedding in weaned pigs. Anim. Feed Sci. Technol. 169, 275-280.

Zhang, H.W., Zhang, Y.H., Lu, M.J., Tong, W.J. \& Cao, G.W., 2007., Comparison of hypertension, dyslipidaemia and hyperglycaemia between buckwheat seed-consuming and non-consuming Mongolian-Chinese populations in Inner Mongolia, China. Clin. Exp. Pharmacol. Physiol. 34, 838-44.

Zhang, Z.L., Zhou, M.L., Tang, Y., Li, F.L., Tang, Y.X., Shao, J.R., Xue, W.T. \& Wu, Y.M., 2012. Bioactive compounds in functional buckwheat food. Food Res. Int. 49, 389-395.

Zheng, G.H., Sosulski, F.W. \& Tyler, R.T., 1998. Wet-milling, composition and functional properties of starch and protein isolated from buckwheat groats. Food Res. Int. 30, 493-502. 